\title{
Pengaruh Suhu dan Waktu Pengeringan terhadap Karakteristik Fisikokimia Buah Naga Merah (Hylocereus polyrhizus (Weber) Britton \& Rose) Kering
}

\section{The Effect of Temperature and Drying Time on the Physicochemical Characteristics of Dried Red Dragon Fruit (Hylocereus polyrhizus (Weber) Britton \& Rose)}

\author{
Indri Novia Santi ${ }^{1}$, I Made Supartha Utama ${ }^{{ }^{*}}$, Ida Ayu Gede Bintang Madrini ${ }^{1}$
}

Diterima 28 Desember 2020/Disetujui 28 April 2021

\begin{abstract}
As one of the horticultural commodities, red dragon fruit (Hylocereus polyrhizus (Weber) Britton \& Rose)) is easily damages after harvesting. This research aims to determine the effects of temperature and drying time on the physico-chemical characteristics of dried red dragon fruit. The experimental design used in the study was a completely randomized design (CRD) with two factors of treatments and three replications. The first factor was drying temperature with three level of treatments, namely 40,50 and $60{ }^{\circ} \mathrm{C}$, and the second factor was drying time with three levels of treatments, namely 15, 20 and 25 hours. The each treatment was replicated three times. The one $\mathrm{cm}$ thickness of sliced flesh red dragon fruit was oven-dried at the different temperature and the different drying times. The results showed that the dyring temperature of $60{ }^{\circ} \mathrm{C}$ and drying time of 20 hours resulted in the best flesh dried fruit based on the color difference between the fleshes dried and the fleshes fresh fruit, texture, yield, water content, water activity, total soluble solids, total tiratable acidity, and vitamin $C$ of the dried fleshes fruit.
\end{abstract}

Keywords: color difference, total soluble solids, total tiratable acidity, water activity

\begin{abstract}
ABSTRAK
Sebagai salah satu komoditas hortikultura, buah naga merah (Hylocereus polyrhizus (Weber) Britton \& Rose) adalah komoditas yang mudah mengalami kerusakan setelah panen. Penelitian ini bertujuan untuk mengetahui pengaruh suhu dan waktu pengeringan terhadap karakteristik fisikokimia buah naga merah kering. Rancangan penelitian yang digunakan adalah rancangan acak lengkap dengan dua faktor perlakuan. Faktor pertama adalah suhu pengeringan terdiri atas tiga taraf, yaitu 40, 50 dan $60{ }^{\circ} \mathrm{C}$ dan faktor ke-dua adalah lama waktu pengeringan terdiri dari tiga taraf, yaitu 15 jam, 20 jam dan 25 jam. Setiap perlakuan diulang sebanyak tiga kali. Potongan melintang buah naga merah dengan ketebalan $1 \mathrm{~cm}$ dikeringkan dengan oven pada suhu dan lama pengeringan sesuai perlakuan. Hasil penelitian menunjukkan bahwa perlakuan suhu $60{ }^{\circ} \mathrm{C}$ dan waktu pengeringan 20 jam menghasilkan buah baga merah kering terbaik berdasarkan nilai perbedaan warna (color difference) antara daging buah segar dan kering, rendemen, kadar air, aktivitas air, padatan terlarut total, asam tertitrasi total, dan vitamin $\mathrm{C}$.
\end{abstract}

Kata kunci: aktivitas air, asam tertitrasi total, color difference, padatan terlarut total

${ }^{1}$ Program Studi Teknik Pertanian dan Biosistem, Fakultas Teknologi Pertanian, Universitas Udayana Jl. Raya Kampus Unud, Bukit Jimbaran, Kuta Selatan, Badung, Bali 803611, Indonesia

E-mail : supartha_utama@unud.ac.id (*penulis korespondensi) 


\section{PENDAHULUAN}

Buah naga atau dragon fruit adalah buah yang populer akhir-akhir ini. Buah ini mulai diusahakan dan dipasarkan di Indonesia pada awal tahun 2003. Buah naga mempunyai prospek penjualan yang bagus, hal ini karena selain budidayanya juga tidak terlalu sulit, bentuk buahnya eksotik, memiliki rasa manis dan ragam manfaat kesehatan bagi manusia. Buah naga seperti buah-buahan pada umumnya termasuk komoditas mudah rusak pada periode pascapanennya (Kader et al., 2002). Kerusakan dapat disebabkan oleh kerusakan fisiologis, mekanis, dan mikrobiologis sehingga buah-buahan secara umum tidak mempunyai umur simpan panjang.

Buah naga juga merupakan buah nonklimaterik dimana buah yang bila dipanen muda tidak akan menjadi matang sehingga pemanenan harus dilakukan pada tingkat kematangan yang optimum. Kematangan optimum terjadi ketika buah masih melekat pada tanaman yang ditandai dengan perubahan warna kulit buah menjadi merah, ukuran buah maksimum, dan meningkatnya akumulasi gula (Widodo et al., 2020). Buah naga dapat dipanen 40 hari setelah berbunga. Pemanenan buah naga dilakukan pada buah naga yang memiliki ciri-ciri warna kulit merah mengkilap dan jumbai atau sisik berubah warna dari hijau menjadi kemerahan. Pemanenan dilakukan menggunakan gunting. Buah ini sudah bisa di panen 40 hari setelah bunga mekar untuk mendapatkan buah yang manis. Umur produktif tanaman buah naga ini berkisar antara 15-20 tahun (Istianingsih dan Efendi, 2013).

Pengeringan merupakan proses pengeluaran air dari dalam bahan, dan proses menggunakan panas untuk menghasilkan produk kering yang bertujuan untuk menghindari kerusakan mikroorganisme, kemunduran fisiologis produk buah segar dan memperpanjang masa simpan (Fellows, 2007; Jangam et al., 2010). Di samping itu, pengeringan buah dapat mengurangi penurunan bobot dan kemasan curah besar, biaya penanganan dan transportasi (ArayaFarias dan Ratti, 2009).

Pengeringan buah sudah dikenal sejak dulu sebagai salah satu metode pengawetan produk pertanian (Guine, 2018). Di dalam pengeringan, faktor-faktor yang berpengaruh terhadap kecepatan pengeringan dan kualitas produk kering yang dihasilkan diantaranya suhu, tekanan, kelembaban udara, kecepatan aliran udara dan lamanya waktu pengeringan (Raponi et al., 2017).

Menurut Sarobol et al. (2018) tentang difusi kelembaban efektif dan energi aktivasi pada pengeringan konvektif dengan udara panas dalam membantu ekstraksi irisan buah naga, menyatakan bahwa waktu pengeringan menurun dengan meningkatnya suhu pengeringan tetapi meningkat dengan menurunnya ketebalan irisan buah naga. Efektivitas tertinggi difusitas kelembaban dari ketebalan lapisan buah $3 \mathrm{~mm}$ didapatkan $3.55 \times 10^{-9} \mathrm{~m}^{2}$ detik $^{-1}$, sedangkan untuk ketebalan $5 \mathrm{~mm}$ didapatkan $9.21 \times 10^{-10} \mathrm{~m}^{2}$ $\operatorname{detik}^{-1}$. Efektivitas difusitas kelembaban meningkat dengan meningkatnya suhu. Marpaung et al. (1995) menunjukkan bahwa pengeringan dengan oven pada suhu $40{ }^{\circ} \mathrm{C}$ yang dikombinasikan dengan prapengeringan, yaitu direndam dalam larutan garam $2 \%$, menghasilkan kadar volatile reduction substances (VRS) yang paling tinggi (340.66 mgrek $\mathrm{g}^{-1}$ ) serta sifat organoleptik terbaik pada irisan kering bawang putih. Menurut Histifarina et al. (2004) bahwa pengeringan dengan oven pada suhu $50{ }^{\circ} \mathrm{C}$ yang dikombinasikan dengan waktu pengeringan 32 jam menghasilkan wortel kering terbaik berdasarkan nilai kadar air $(9.15 \% \mathrm{bb})$, kadar beta karoten $(0.019 \%)$, persentase rehidrasi tinggi $(520.44 \%)$, dan penilaian sensori terhadap warna serta tekstur yang baik. Mohamed et al. (1994) menyatakan bahwa suhu pengeringan $60{ }^{\circ} \mathrm{C}$ memerlukan waktu pengeringan 22 jam sampai diperoleh berat konstan (kadar air $\pm 9.89 \%$ ), sedangkan suhu $40{ }^{\circ} \mathrm{C}$ membutuhkan waktu selama 42 jam.

Sampai saat ini penelitian tentang pengaruh suhu dan waktu pengeringan terhadap karakteristik fisikokimia buah naga merah masih terbatas dan hal ini yang melandasi penelitian pengeringan ini dilaksanakan dengan ragam suhu 40, 50 dan 60 ${ }^{\circ} \mathrm{C}$ dan waktu pengeringan selama 15,20 dan 25 jam. Tujuan penelitian ini adalah untuk mengetahui pengaruh suhu dan waktu pengeringan terhadap karakteristik fisikokimia daging buah naga merah kering. 


\section{BAHAN DAN METODE}

Penelitian dilaksanakan pada bulan September sampai Oktober 2020. Bahan penelitian buah naga merah didapatkan dari eksporter PT. Bali Organik Subak yang dipanen sehari sebelumnya di daerah perkebunan di Desa Bulian, Kecamatan Kubutambahan, Kabupaten Buleleng dengan umur panen 40-45 hari setelah bunga mekar. Buah untuk penelitian dipilih yang utuh tidak mengalami kerusakan dan cacat fisik dengan bobot 451-600 g dan diameter pada bagian equatornya $10-12 \mathrm{~cm}$.

Penelitian menggunakan Rancangan Acak Lengkap (RAL) dengan dua faktor, yaitu suhu pengeringan $\left(40,50\right.$ dan $\left.60{ }^{\circ} \mathrm{C}\right)$ dan waktu pengeringan $(15,20$ dan 25 jam). Setiap perlakuan diulang 3 kali sehingga terdapat 18 satuan percobaan. Setiap satuan percobaan menggunakan tiga butir buah naga merah yang diiris melintang dengan ketebalan $1 \mathrm{~cm}$ dan yang digunakan dalam penelitian adalah lima irisan pada bagian equator. Kulit atau pericarp irisan dilepas sehingga hanya tinggal daging buah yang diperlakukan pengeringan. Pengeringan dilakukan menggunakan oven elektrik (Labo Japan) dengan suhu dan lama pengeringan sesuai perlakuan.

Variabel fisikokimia buah hasil pengeringan yang diamati pada penelitian ini meliputi perbedaan warna (color difference) antara daging buah segar dengan daging buah hasil pengeringan, tekstur, rendemen, kadar air, aktivitas air, padatan terlarut total, asam tertitrasi total, dan vitamin $\mathrm{C}$ daging buah kering.

\section{Kadar Air}

Kadar air merupakan salah satu karakteristik fisik yang menunjukkan banyaknya kandungan air di dalam bahan. Pengukuran kadar air menggunakan metode oven dengan menempatkan $15 \mathrm{~g}$ sampel dalam cawan logam dengan diameter $6.5 \mathrm{~cm}$ tinggi $5.5 \mathrm{~cm}$ dan dipanaskan dalam oven (Labo, Japan) dengan suhu $105{ }^{\circ} \mathrm{C}$ selama 24 jam (Carneiro et al., 2018). Perhitungan kadar air berbasis basah diperlihatkan di bawah ini:

Kadar Air (\%) $=\frac{\text { (bobot awal-berat akhir) }}{\text { bobot awal }} \times 100 \% \ldots$ (3)

Aktivitas Air (a $\left.\mathbf{a}_{w}\right)$

Pengukuran aktivitas air daging buah naga kering dilakukan menggunakan $a_{w}$ meter
(Pre Aqua Lab). Sebelum melakukan pengukuran, alat dihubungkan ke tenaga listrik. Sampel buah kering diletakkan dalam $\mathrm{a}_{\mathrm{w}}$ meter yang telah dihubungkan dengan tenaga listrik. Jika sudah dalam posisi ready, tombol diputar ke arah read, kemudian nilai $\mathrm{a}_{\mathrm{w}}$ terbaca bila alat tersebut dalam posisi completed (Suharyanto, 2009).

\section{Tekstur}

Tekstur irisan buah naga merah kering diukur menggunakan Texture Analyzer (TA XT Plus, England). Dengan alat ini daging buah kering ditekan menggunakan probe berdiameter $6 \mathrm{~mm}$ dan luas penampang 0.282 $\mathrm{cm}^{2}$ sampai kedalaman $5 \mathrm{~mm}$ selama 10 detik. Hasil tekanan merupakan nilai tekstur dengan satuan kg force (tekanan).

\section{Rendemen}

Rendemen merupakan perbandingan berat produk yang diperoleh terhadap berat bahan baku yang digunakan. Perhitungan rendemen diperlihatkan pada formula di bawah ini.

Rendemen $(\%)=\frac{\text { bobot akhir }}{\text { bobot awal }} \times 100 \% \ldots$

\section{Color Difference}

Color difference menyatakan perubahan warna yang terjadi pada daging buah naga merah kering dibandingkan dengan daging buah segar. Nilai kromatik $L^{*}, a^{*}$ dan $b^{*}$ (Abbot, 1999) diukur menggunakan Colorimeter (PCE Model PCE-CSM 1, USA) masing-masing sebanyak tiga kali pada bagian tengah irisan daging buah kering, selanjutnya hasil pengukuran diratakan. Color difference selanjutnya dihitung berdasakan formula yang dipublikasikan oleh Rhim et al. (1999) di bawah ini.

$$
\begin{aligned}
& \Delta \mathrm{E}=\sqrt{\Delta L^{* 2}+\Delta a^{* 2}+\Delta b^{* 2}} \ldots \text { (1) } \\
& \text { Keterangan: } \\
& \Delta \mathrm{E}=\text { Nilai total color difference } \\
& \Delta \mathrm{L}^{*}=\text { selisih nilai } L^{*} \text { buah kering }-L^{*} \text { buah } \\
& \text { segar } \\
& \Delta \mathrm{a}^{*}=\text { selisih nilai } a^{*} \text { buah kering }-a^{*} \text { buah } \\
& \text { segar } \\
& \Delta \mathrm{b}^{*}=\text { selisih nilai } b^{*} \text { buah kering }-b^{*} \text { buah } \\
& \text { segar }
\end{aligned}
$$

\section{Padatan Terlarut Total}

Padatan terlarut total diamati menggunakan refractometer digital (Atago, 
Japan). Refraktometer terlebih dahulu dikalibrasi dengan meneteskan akuades pada prisma dan diatur nilai ukurnya adalah nol. Sampel yang diukur dihancurkan atau dihaluskan terlebih dahulu kemudian disaring menggunakan kertas saring. Hasil cairan kemudian diteteskan di atas prisma refractometer dan dilihat nilai ukur dalam satuan ${ }^{\circ}$ Brix. Setiap akan dilakukan pengukuran, prisma refractometer dibersihkan dengan akuades secukupnya dan dikalibrasi menggunakan akuades.

\section{Asam Tertitrasi Total}

Pengukuran nilai total asam tertitrasi dilakukan menggunakan metode titrasi. Sampel di timbang sebanyak $1 \mathrm{~g}$ dihaluskan dan dimasukkan ke dalam gelas beaker, selanjutnya di encerkan dengan $100 \mathrm{ml}$ akuades. Hasil pengenceran disaring menggunakan kertas saring dan sebanyak 10 ml filtrat di titrasi menggunakan $0.1 \mathrm{~N} \mathrm{NaOH}$ yang ditambahkan indikator fenolftalin (pp) sebanyak 3 tetes sampai berwarna merah mudah. Perhitungan total asam tertitrasi dapat dihitung formula berikut (Pundari et al., 2019) Total Asam Tertitrasi (\%) $=\frac{\text { Vol NaOH X N NaOH XP }}{\mathrm{m}} \times 100 \ldots$ (4) Keterangan:

Vol = volume larutan $\mathrm{NaOH}(\mathrm{ml})$

$\mathrm{N} \quad=$ normal larutan $\mathrm{NaOH}$

$\mathrm{P} \quad=$ pengenceran

$\mathrm{M} \quad=$ bobot sampel $(\mathrm{g})$

\section{Vitamin C}

Pengukuran kadar vitamin $\mathrm{C}$ dilakukan dengan menimbang sebanyak $10 \mathrm{~g}$, kemudian dihancurkan atau dihaluskan, lalu dimasukkan ke dalam gelas beaker dan di encerkan dengan menambahkan akuades sebanyak $100 \mathrm{ml}$, kemudian di saring dengan kertas saring. Selanjutnya sebanyak $10 \mathrm{ml}$ filtrat ditambahkan indikator amilum sebanyak $1 \mathrm{ml}$ dan di titrasi dengan $\operatorname{Iod}(0.096 \mathrm{~N})$ hingga warna berubah menjadi ungu yang stabil selama 15 detik. Kadar vitamin $\mathrm{C}$ dihitung menggunakan formula (Pundari et al., 2019) berikut:

Vitamin C $(\mathrm{mg} / 100 \mathrm{~g})=\frac{\mathrm{ml} \text { titrasi } \times 0.88 \times \mathrm{fp} \times 100}{\mathrm{w} \text { sampel }} \ldots(5)$

Keterangan:

$\mathrm{ml}$ titrasi $=$ volume iod $\mathrm{N}$ yang digunakan untuk mengubah filtrat dari bening menjadi biru muda

$\mathrm{fp}=$ faktor pengenceran w sampel $=$ bobot sampel yang digunakan untuk menghasilkan filtrat

\section{Analisis Data}

Keragaman data dianalisis secara statistik dan bila perlakuan berpengaruh nyata terhadap keragaman data, maka dilanjutkan dengan Uji Jarak Berganda Duncan.

\section{HASIL DAN PEMBAHASAN}

\section{Kadar Air}

Berdasarkan analisis keragaman didapatkan bahwa perlakuan suhu pengeringan berpengaruh nyata $(\mathrm{P} \leq 0.05)$ terhadap kadar air buah kering, sedangkan perlakuan waktu pengeringan tidak berpengaruh nyata $(\mathrm{P}>0.05)$. Pengaruh nyata dari suhu pengeringan didapatkan pada suhu $60{ }^{\circ} \mathrm{C}$ di bandingkan dengan 40 dan $50{ }^{\circ} \mathrm{C}$. Kedua suhu yaitu 40 dan $50{ }^{\circ} \mathrm{C}$ tidak berbeda nyata pengaruhnya terhadap kadar air daging buah naga merah kering. Ini menunjukkan bahwa lama waktu pengeringan 15, 20 dan 25 jam atau suhu 40 dan $50{ }^{\circ} \mathrm{C}$ pada setiap lama waktu pengeringan tidak efektif menurunkan kadar air daging buah naga, dan hanya suhu $60{ }^{\circ} \mathrm{C}$ dengan lama pengeringan 15-25 jam yang dapat menurunkan kadar air secara nyata menjadi berkisar $14.43 \%$ sampai $20.20 \%$ (Gambar 1).

Kadar air daging buah naga segar sekitar $87.9 \%$ (Islam et al., 2012) memerlukan waktu untuk menguapkan air permukaan daging buah untuk memungkinkan terjadinya difusi dan penguapan air di dalam buah ke udara sekitar. Kondisi laju penguapan konstan air permukaan buah dengan lama waktu 15 sampai 25 jam dapat dipercepat dengan suhu pengeringan $60{ }^{\circ} \mathrm{C}$ dibandingkan dengan suhu 40 dan $50{ }^{\circ} \mathrm{C}$ pada lama waktu yang sama, sehingga memberikan hasil kadar air buah kering nyata lebih kecil. Laju pengeringan konstan dapat berlangsung lebih lama tergantung kemampuan air dalam bahan berdifusi membentuk air permukaan yang selalu tersedia untuk diuapkan (Srikiatden, 2007). Selain itu, kekuatan pengendali difusi air jaringan bahan untuk menjadi air bebas adalah tekanan osmotik dari larutan osmotik dan rendahnya aktivitas air yang berakibat pada transfer air melewati dinding sel (Yadav dan Singh, 2014). 
Pada penelitian ini, kondisi kadar air $14.43 \%$ sampai $20.20 \%$ didapatkan aktivitas air $\left(\mathrm{a}_{\mathrm{w}}\right)$ berkisar 0.51 sampai 0.77 , yaitu pada suhu pengeringan $60{ }^{\circ} \mathrm{C}$. Kadar air dan aktivitas air terendah berturut-turut yaitu $14.43 \%$ dan 0.51 didapatkan pada perlakuan suhu $60{ }^{\circ} \mathrm{C}$ dan lama pengeringan $25 \mathrm{jam}$, dan dilihat dari kemungkinan serangan mikroorganisme serta adanya aktivitas enzim buah maka kondisi ini adalah terbaik untuk meminimalkan dan bahkan meniadakan kedua aktivitas tersebut.

Persyaratan atau standar kadar air buah kering sangat beragam. Standar Nasional Indonesia (SNI 01-3710-1995) mempersyaratkan kadar air buah kering secara umum maksimum $31 \%$ b/b (BSN, 1995). Sedangkan the United Nations Economic Commission for Europe (UNECE) mempersyaratkan kadar air buah kering spesifik untuk jenis buahnya, yaitu untuk daging buah mangga kering tanpa pengawet $15 \%$ dan dengan pengawet di atas $15 \%$ tapi tidak melebihi 35\% (UNECE, 2013). Sedangkan untuk buah nenas kering tanpa pengawet tidak melebihi $20 \%$ dan buah nenas kering dengan pengawet dapat lebih dari $20 \%$ tapi tidak melebihi 44\% (UNUCE, 2014), khusus untuk kadar air buah naga kering belum ada standarnya.

\footnotetext{
Aktivitas Air $\left(\mathbf{a}_{\mathbf{w}}\right)$

Aktivitas air $\left(a_{\mathrm{w}}\right)$ menunjukkan adanya air bebas yang dapat dimanfaatkan untuk pertumbuhan dan perkembangan mikroorganisme dengan nilai maksimum 1 . Hasil analisis keragaman menunjukkan bahwa pengaruh suhu dan lama waktu pengeringan berinteraksi dan berpengaruh nyata $(\mathrm{P} \leq 0.05)$ terhadapat nila $\mathrm{a}_{\mathrm{w}}$ daging buah naga merah kering. Pada Gambar 2 terlihat pengaruh perbedaan suhu hanya terjadi secara nyata pada lama pengeringan 25 jam dan nilai $a_{w}$ terendah yaitu 0.51 pada suhu pengeringan 60 ${ }^{\circ} \mathrm{C}$. Demikian pula pengaruh perbedaan lama pengeringan secara nyata hanya terjadi pada suhu pengeringan $60{ }^{\circ} \mathrm{C}$ dan nilai $\mathrm{a}_{\mathrm{w}}$ terkecil yaitu 0.51 pada lama pengeringan 25 jam. Pengaruh suhu $60{ }^{\circ} \mathrm{C}$ dan lama pengeringan 25 jam ini tidak berbeda nyata dengan suhu $60{ }^{\circ} \mathrm{C}$ dan lama waktu pengeringan 20 jam dengan
}

nila $a_{w}$ 0.64. Nilai $a_{w}$ yang relatif kecil ini berkaitan dengan kadar air buah kering. Pada kondisi yang sama yaitu suhu $60{ }^{\circ} \mathrm{C}$ dan lama pengeringan $20 \mathrm{jam}$, kadar airnya juga relatif kecil yaitu $17.77 \%$ (Gambar 1).

Aktifitas air untuk bahan pangan penting selain menunjukkan ketersediaan air bebas untuk pertumbuhan dan perkembangan mikroorganisme, juga menunjukkan stabilitas reaksi kimia, nilai nutrisi, warna, rasa, tekstur dan daya simpan (Sandulachi, 2012). Pada buah kering $a_{w} 0.7$ (kadar air sekitar 18\%) mikroorganisme yang tumbuh umumnya bakteri halofilik, sedangkan pada $\mathrm{a}_{\mathrm{w}} 0.8$ umumnya yang tumbuh adalah jamur, pada $\mathrm{a}_{\mathrm{w}}$ 0.88 adalah yeast atau ragi, dan $\mathrm{a}_{\mathrm{w}} 0.9$ adalah bakteri (Safefood 360 Inc, 2014). Hasil daging buah naga kering yang terbaik dari penelitian ini adalah $0.51-0.64$ dengan kadar air $14.43 \%$ dan $17.77 \%$ berasal dari perlakuan suhu pengeringan $60{ }^{\circ} \mathrm{C}$ dengan lama pengeringan 25 dan 20 jam diperkirakan telah dapat menekan aktivitas enzim serta pertumbuhan dan perkembangan mikroorganisme. Hal ini sejalan dengan pendapat Rahman (2005) bahwa pada aktivitas yang rendah dapat menghambat pertumbuhan berbagai mikroorganisme dan mencegah oksidasi dan reaksi enzimatik dalam buah. Bahkan diperkuat oleh Ong and Law (2010) bahwa pada kebanyakan buah kering dengan aktivitas air kurang dari 0.6 adalah level rekomendasi untuk penyimpanan yang aman.

\section{Tekstur}

Analisis keragaman menunjukkan adanya pengaruh interaksi perlakuan suhu dan lama pengeringan secara nyata terhadap tekstur daging buah naga merah kering $(\mathrm{P} \leq 0.05)$. Pengaruh nyata dari suhu terjadi pada seluruh perlakuan lama pengeringan (15, 20 dan 25 jam) $(\mathrm{P} \leq 0.05)$, dimana dengan suhu pengeringan $60{ }^{\circ} \mathrm{C}$ dan lama pengeringan 25 jam memberikan nilai tekstur nyata tertinggi (6.21 kg force) dibandingkan dengan suhu pengeringan $40{ }^{\circ} \mathrm{C}$ dan $50{ }^{\circ} \mathrm{C}$. Demikian pula lama pengeringan adalah berpengaruh nyata $(\mathrm{P} \leq 0.05)$ pada setiap suhu pengeringan, di mana semakin tinggi lama pengeringan maka semakin tinggi teksturnya (Gambar 3). 


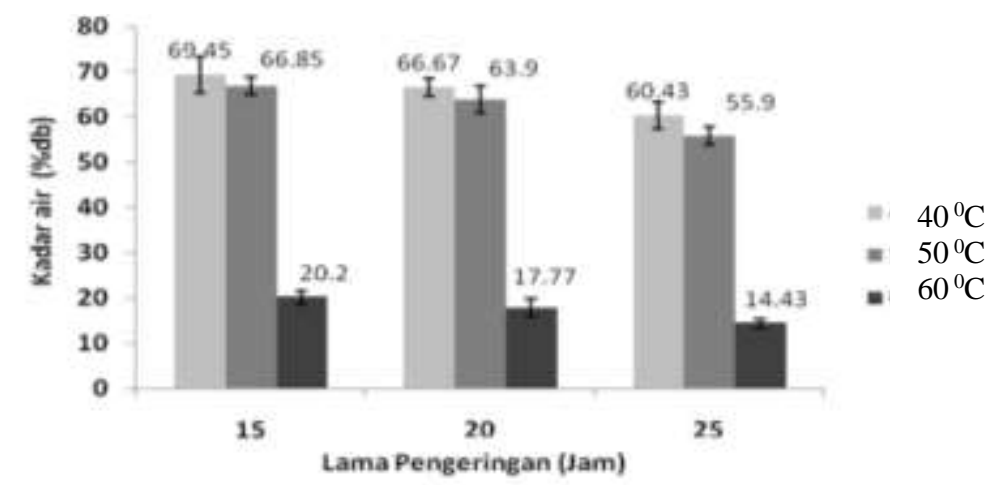

Gambar 1. Pengaruh suhu dan waktu pengeringan terhadap kadar air daging buah naga merah kering. Garis kecil pada histogram menunjukkan standard deviasi data.

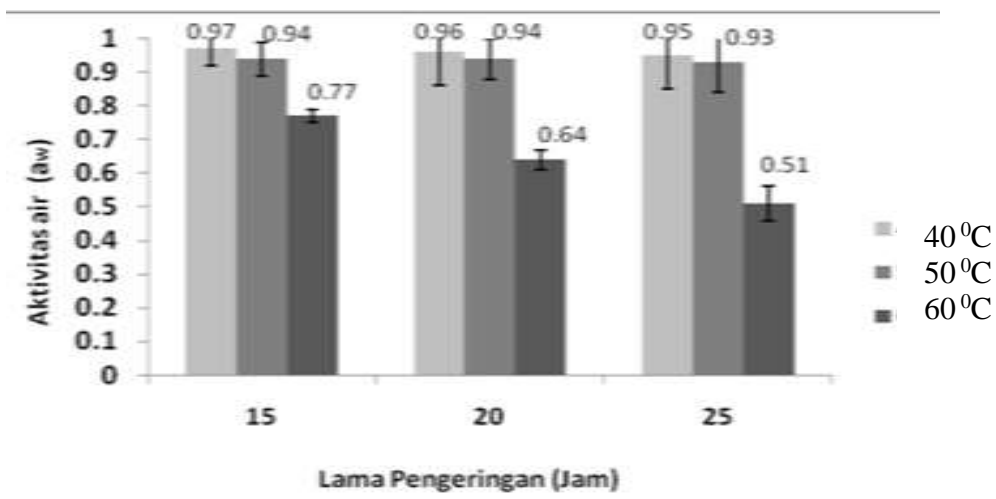

Gambar 2. Pengaruh suhu dan waktu pengeringan terhadap aktivitas air daging buah naga merah kering. Garis kecil pada histogram menunjukkan standard deviasi data.

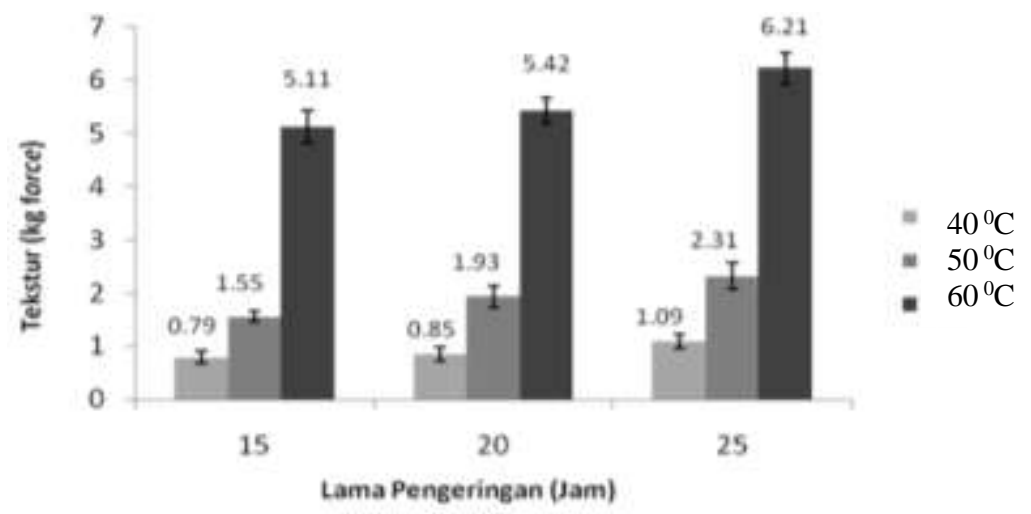

Gambar 3. Pengaruh suhu dan waktu pengeringan terhadap tekstur daging buah naga merah kering. Garis kecil pada histogram menunjukkan standard deviasi data.

Perubahan tekstur daging buah naga merah kering pada penelitian ini berhubungan dengan perubahan kadar air dan aktivitas air, di mana semakin tinggi semakin menurunnya kadar air dan aktivitas air (Gambar 1 dan 2). Pengaruh ini sangat nyata terjadi pada suhu pengeringan $60^{\circ} \mathrm{C}$ pada lama pengeringan 25 jam dibandingkan dengan lama pengeringan 15 dan 20 jam. Sedangkan pada suhu pengeringan $40{ }^{\circ} \mathrm{C}$ atau $50{ }^{\circ} \mathrm{C}$ cenderung berpengaruh tidak nyata dengan adanya perubahan lama pengeringan (15-25 jam). Pada kondisi ini, tekstur daging buah masih rendah sejalan dengan tingginya kadar $(55.90 \%$ - 69.45\%) dan aktivitas air (0.930.97). Berubahnya struktur dalam bahan pangan karena pengeluaran air berakibat pada perubahan tekstur (Yan et al. 2008; Ong and Law, 2010). Mengkerutnya volume pada 
bahan biologis didapatkan sebagai fungsi dari kadar air (Hashemi et al. 2009).

\section{Rendemen}

Analisis keragaman menunjukkan interaksi perlakuan suhu dan lama waktu pengeringan berpengaruh secara nyata terhadap rendemen daging buah naga merah kering $(\mathrm{P} \leq 0.05)$. Gambar 4 memperlihatkan bahwa semakin tinggi suhu dan lama pengeringan maka semakin menurun rendemen daging buah naga merah kering. Suhu $40{ }^{\circ} \mathrm{C}$ dengan $60{ }^{\circ} \mathrm{C}$ pada lama waktu pengeringan yang sama berpengaruh nyata terhadap rendemen, namun kedua suhu tersebut tidak berbeda nyata pengaruhnya dibandingkan suhu $50{ }^{\circ} \mathrm{C}$. Berbeda dengan pengaruh lama pengeringan $(15,20$ dan 25 jam) pada suhu yang sama berbeda nyata terhadap rendemen buah kering. Tinggi rendahnya rendemen tergantung pada kadar air. Semakin tinggi kadar air, maka rendemen semakin tinggi dan sebaliknya. Buah kering dengan kadar air yang tinggi berisiko terhadap pertumbuhan mikroorganisme akibat aktivitas air $\left(a_{w}\right)$ yang tinggi, seperti dijelaskan pada parameter aktivitas air. Pengkerutan buah yang mencirikan menurunnya rendemen berkaitan dengan kadar air dijelaskan oleh Hashemi et al. (2009) bahwa mengkerutnya bahan biologis di dalam proses pengeringan adalah sebagai fungsi dari kadar air.

\section{Color Difference}

Hasil analisis keragaman menunjukkan bahwa suhu dan waktu pengeringan berpengaruh nyata $(\mathrm{P} \leq 0.05)$, sedangkan interaksi tidak berpengaruh nyata $(\mathrm{P}>0.05)$ terhadap keragaman data color difference. Gambar 5 menunjukkan semakin tinggi suhu pengeringan maka semakin tinggi perbedaan dari warna daging buah naga kering dengan warna daging buah segar. Namun perbedaan data secara nyata terjadi antara perlakuan suhu pengeringan $40{ }^{\circ} \mathrm{C}$ dan $60{ }^{\circ} \mathrm{C}$. Demikian pula semakin lama pengeringan, semakin tinggi perbedaan warna, namun secara nyata perbedaan tersebut diperlihatkan oleh lama waktu pengeringan 15 jam dan 25 jam. Suhu pengeringan $60{ }^{\circ} \mathrm{C}$ atau lama pengeringan 25 jam menyebabkan perbahan warna daging buah kering secara nyata dan secara deskriptif warna buah menunjukkan merah kecoklatan. Warna ini dapat terjadi karena adanya pencoklatan non-enzimatis melalui reaksi Mailard dengan adanya suhu atau lama waktu relatif panjang dalam pengeringan daging buah. Reaksi Mailard terjadi karena terbentuknya ikatan kompleks antara asam amino dan gula reduksi (Winarno, 2004; Sabrina dan Susanto, 2017; Somjai et al., 2021).

\section{Padatan Terlarut Total (PTT)}

Berdasarkan analisis keragaman didapatkan interaksi suhu dan lama pengeringan berpengaruh nyata terhadap PTT. Penurunan nilai PTT secara nyata terjadi ketika suhu ditingkatkan dari $40{ }^{\circ} \mathrm{C}$ ke $60{ }^{\circ} \mathrm{C}$ pada lama waktu pengeringan 20 dan 25 jam $(\mathrm{P} \leq 0.05)$, sedangkan pada lama waktu 15 jam pengaruhnya tidak nyata $(\mathrm{P}>0.05)$ jam. Pengaruh lama pengeringan hanya nyata $(\mathrm{P} \leq 0.05)$ pada suhu pengeringan $50{ }^{\circ} \mathrm{C}$, sedangkan pada suhu $40{ }^{\circ} \mathrm{C}$ dan $60{ }^{\circ} \mathrm{C}$ tidak berpengaruh nyata $(\mathrm{P}>0.05)$. Penurunan nyata PTT pada suhu $40-60{ }^{\circ} \mathrm{C}$ dan lama pengeringan 20 dan 25 jam berkaitan dengan adanya peningkatan nyata reaksi pencoklatan nonenzimatik. Seperti disebutkan oleh Somjai et al. (2021), gula reduksi mengalami ikatan kompleks dengan asam amino. Pada penelitian ini diindikasikan oleh adanya peningkatan nyata color difference pada kondisi atau perlakuan pengeringan yang sama (Gambar 5). 


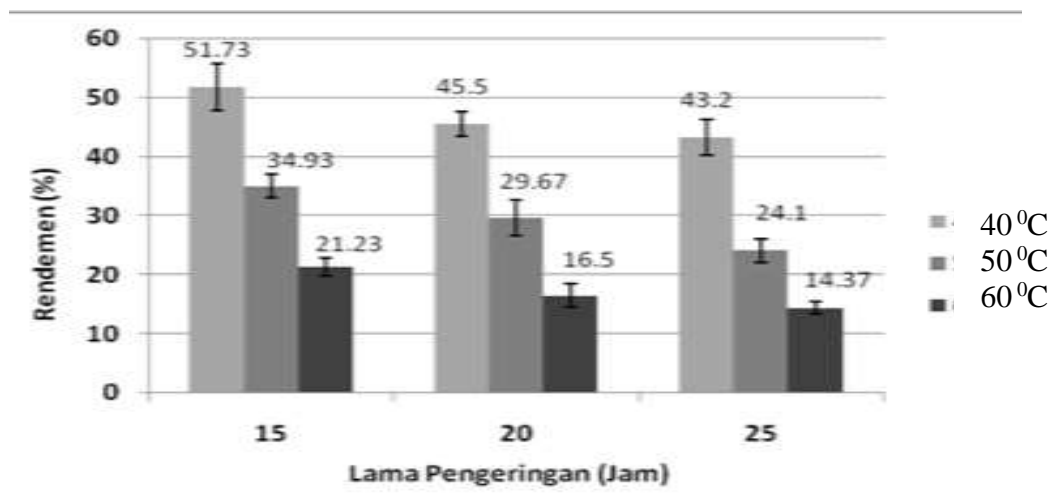

Gambar 4. Pengaruh suhu dan waktu pengeringan terhadap rendemen daging buah naga merah kering. Garis kecil pada histogram menunjukkan standard deviasi data.

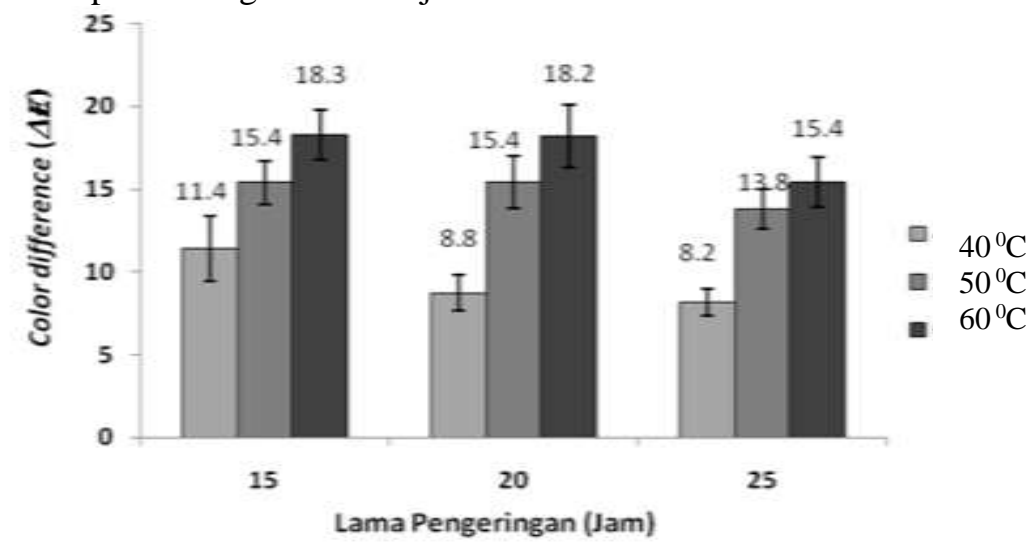

Gambar 5. Pengaruh suhu dan waktu pengeringan terhadap color difference antara warna daging buah kering dengan daging buah naga merah segar. Garis kecil pada histogram menunjukkan standard deviasi data.

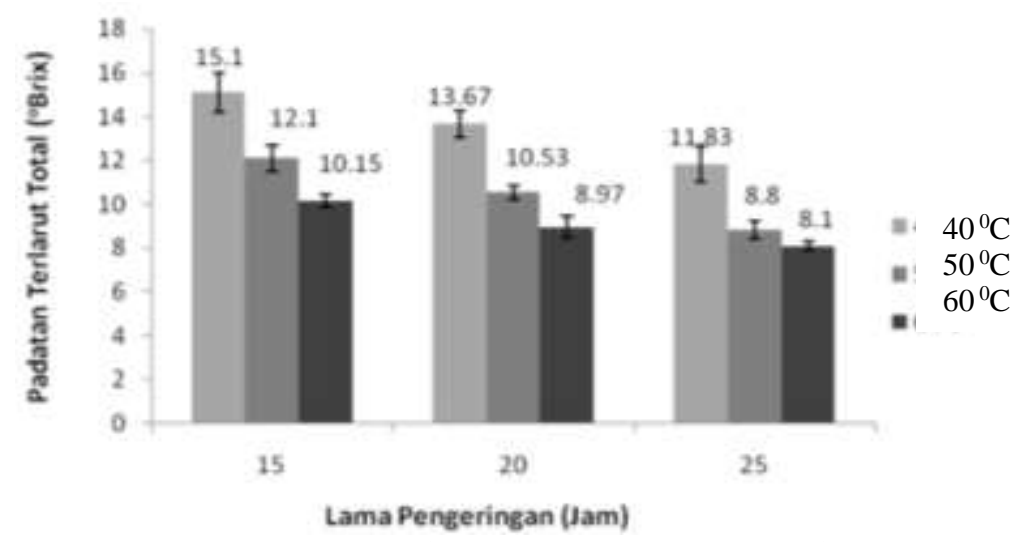

Gambar 6. Pengaruh suhu dan waktu pengeringan terhadap padatan terlarut total daging buah naga merah kering. Garis kecil pada histogram menunjukkan standard deviasi data.

\section{Asam Tertitrasi Total (ATT)}

Hasil analisis keragaman menunjukkan perlakuan suhu pengeringan berpengaruh nyata $(\mathrm{P} \leq 0.05)$ sedangkan perlakuan lama pengeringan tidak berpengaruh nyata $(\mathrm{P}>0.05)$ terhadap ATT. Dari perlakuan suhu pengeringan didapatkan bahwa suhu $60{ }^{\circ} \mathrm{C}$ memberikan nilai ATT rata-rata nyata tertinggi
$(\mathrm{P}<0.05)$, yaitu $1.60 \%$ dibandingkan dengan suhu $40{ }^{\circ} \mathrm{C}$ dan $50{ }^{\circ} \mathrm{C}$ pada kisaran lama pengeringan 15-25 jam, dimana kedua perlakuan ini tidak berpengaruh nyata terhadap nilai ATT dengan nilai yaitu berturut-turut $0.85 \%$ dan $0.91 \%$. Pengaruh suhu ini diperkirakan berkaitan erat dengan kadar air dan aktivitas air yang nyata lebih rendah pada 
suhu pengeringan $60{ }^{\circ} \mathrm{C}$ dibandingkan dengan suhu pengeringan $40{ }^{\circ} \mathrm{C}$ dan $50{ }^{\circ} \mathrm{C}$ dimana pada kedua suhu pengeringan ini tidak berpengaruh nyata (lihat Gambar 1 dan 2). Menurut Lubis (2014) adanya hidrokoloid pada daging buah naga merah, yang berperan sebagai pektin untuk pengental ataupun pengikat dapat mengikat gula, air dan padatan terlarut seperti asam-asam dalam bahan, dan peningkatan total asam dikarenakan semakin banyaknya gula yang terhidrolisis menjadi asam. Ditambahkan oleh Tjahyadi (2008) bahwa peningkatan asam pada bahan pangan dapat terjadi karena penguraian glukosa menjadi asam.

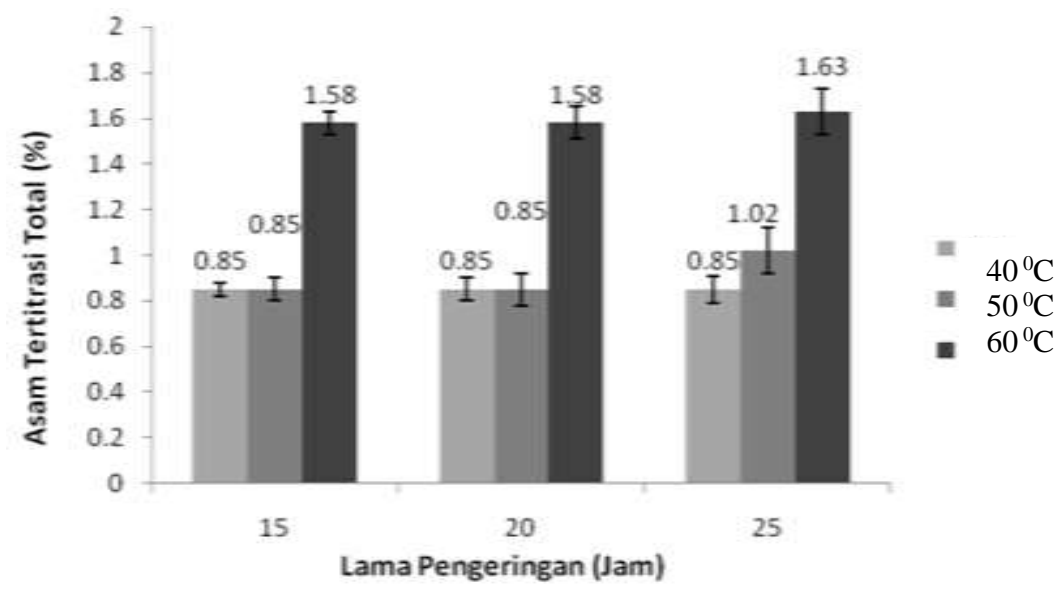

Gambar 7. Pengaruh suhu dan waktu pengeringan terhadap asam tertitrasi total daging buah naga merah kering. Garis kecil pada histogram menunjukkan standard deviasi data.

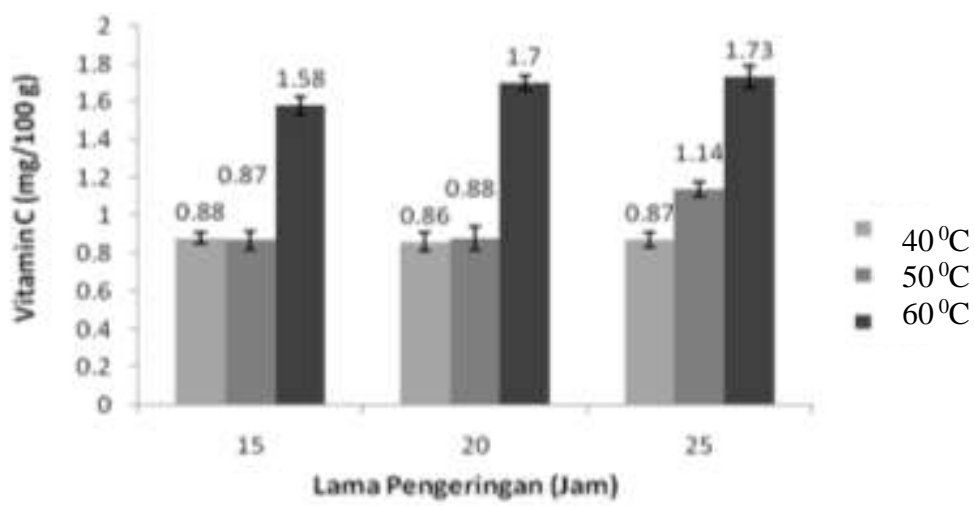

Gambar 8. Pengaruh suhu dan waktu pengeringan terhadap kadar vitamin $\mathrm{C}$ daging buah naga merah kering. Garis kecil pada histogram menunjukkan standard deviasi data.

\section{Vitamin C}

Berdasarkan hasil analisis keragaman didapatkan adanya interaksi pengaruh suhu dan lama pengeringan secara nyata $(\mathrm{P}<0.05)$ terhadap kadar vitamin $\mathrm{C}$ daging buah naga merah kering. Pengaruh suhu pengeringan 50 dan $60{ }^{\circ} \mathrm{C}$ berpengaruh berbeda nyata $(\mathrm{P}<0.05)$ pada setiap lama pengeringan, sedangkan suhu pengeringan 40 dan $50^{\circ} \mathrm{C}$ hanya berpengaruh nyata pada lama pengeringan 25 jam. Pengaruh lama pengeringan berpengaruh nyata pada suhu pengeringan 50 dan $60{ }^{\circ} \mathrm{C}$, sedangkan pada suhu $40{ }^{\circ} \mathrm{C}$ tidak berpengaruh nyata (Gambar 8). Nilai kadar vitamin $\mathrm{C}$ buah daging naga merah kering didapatkan lebih tinggi secara nyata pada suhu $60{ }^{\circ} \mathrm{C}$ pada setiap lama penyimpanan dibandingkan suhu pengeringan lainnya. Kadar vitamin $\mathrm{C}$ pada daging buah naga merah segar adalah lebih tinggi yaitu sekitar $5.28 \mathrm{mg} 100 \mathrm{~g}^{-1}$ (Risnayanti et al., 2015) dibandingkan dengan kadar vitamin $\mathrm{C}$ pada hasil penelitian ini akibat akibat pengaruh suhu dan lama pengeringan secara keseluruhan yaitu berkisar $0.88-1.73$ $\mathrm{mg} 100 \mathrm{~g}^{-1}$. Hal ini kemungkinan disebabkan penurunan secara drastis kadar vitamin $\mathrm{C}$ 
dengan suhu $40-60{ }^{\circ} \mathrm{C}$ telah terjadi selama 15 jam dari saat mulainya pengeringan. Sedangkan perbedaan kadar vitamin $\mathrm{C}$ akibat suhu pengeringan setelah periode 15 jam sampai 25 jam lama pengeringan lebih disebabkan oleh adanya proses meningkatnya pengentalan gel akibat berkurangnya kadar air pada daging buah naga kering yang dapat melindungi vitamin $\mathrm{C}$ dari proses oksidasi. Namun mekanisme ini perlu diteliti lebih lanjut.

\section{KESIMPULAN}

Secara umum pengaruh suhu $(40,50$ dan $\left.60{ }^{\circ} \mathrm{C}\right)$ dan lama pengeringan $(15,20$ dan 25 jam) secara berinteraksi berpengaruh nyata terhadap karakteristik fisikokimia daging buah naga kering, kecuali kadar air dan asam tertitrasi total yang nyata hanya dipengaruhi oleh suhu pengeringan, dan color difference dimana suhu dan lama pengeringan berpengaruh nyata secara individu.

Terdapat pola perubahan karakteristik fisik daging buah naga merah yang saling berkaitan akibat pengaruh suhu dan lama pengeringan. Menurunnya kadar air berakibat pada menurunnya aktivitas air dan rendemen, dan meningkatnya tekstur serta color difference antara daging buah naga kering dengan daging buah naga segar.

Perubahan karakteristik fisik secara nyata pada buah kering dengan suhu pengeringan $60{ }^{\circ} \mathrm{C}$ dan lama pengeringan 25 jam dibandingkan suhu pengeringan lebih rendah dan lama pengeringan lebih singkat.

Padatan terlarut total daging buah naga merah kering nyata lebih rendah akibat suhu pengeringan $60^{\circ} \mathrm{C}$ dan lama pengeringan 25 jam. Pada kondisi yang sama, asam tertitrasi total dan kadar vitamin $\mathrm{C}$ nyata lebih tinggi dibandingkan suhu pengeringan lebih rendah dan lama pengeringan lebih singkat.

Berdasarkan kadar air dan aktivitas air daging buah naga merah kering maka suhu pengeringan $60{ }^{\circ} \mathrm{C}$ dan lama pengeringan 20 jam adalah terbaik karena efisien untuk mencegah kemungkinan adanya pertumbuhan dan perkembangan mikroorganisme pembusuk.

\section{DAFTAR PUSTAKA}

Abbott, J.A. 1999. Quality measurement of fruits and vegetables. Postharvest. Biol. Tec. 15:207-225.

Araya-Farias, M., C. Ratti. 2009. Dehydration of foods; In Ratti, C., Advances in Food Dehydration. CRC Press, Boca Raton, Florida. pp.1-3.

[BSN] Badan Standarisasi Nasional. 1995. Standar Nasional Indonesia: Buah Kering SNI 01-3710-1995. Jakarta

Carneiro, J.S., R.M. Nogueira, M.A. Martins, D.M.S. Valladão, E.M. Pires. 2018. The oven-drying method for determination of water content in Brazil nut. Biosci. J. 34(3): 595-602. Doi: 10.14393/BJ-v34n3a2018-37726.

Fellows, P. (2007). Food processing technology. Woodhead publishing limited, Cambridge, England. pp 311316.

Guiné, R.P.F. 2018. The Drying of foods and its effect on the physical-chemical, sensorial and nutritional properties. Int. J. Food Eng. 4(2).

Hashemi, G., D. Mowla, M. Kazemeini. 2009. Moisture diffusivity and shrinkage of broad beans during bulk drying in an inert medium fluidized bed dryer assisted by dielectric heating. J. Food. Eng. 92: 331-338.

Histifarina, D., D. Musaddad, E. Murtiningsih. 2004. teknik pengeringan dalam oven untuk irisan wortel kering bermutu. J. Hortikultura. 14(2): 107-112.

Islam, M.Z., M.T.H. Khan, M.M. Hoque, M.M. Rahman. 2012. Studies on the processing and preservation of dragon fruit (Hylocereus undatus) jelly. The Agriculturists. 10(2): 29-35. 
Istianingsih, T., D. Efendi. 2013. Pengaruh umur panen dan suhu simpan terhadap umur simpan buah naga super red (Hylocereus costaricensis). J. Hort. Indonesia. 4(1): 54-61.

Jangam, S.V., C.L. Law, A.S. Mujumdar. 2010. Drying of Foods, Vegetables and Fruits. Singapore. pp31.

Kader, A.A., N.F. Sommer, M.L. Arpaia. 2002. Postharvest Handling Systems: Tropical Fruit. In Postharvest Technology of Horticultural Crops, $3^{\text {rd }}$ Ed. Edt by A.A. Kader. Postharvest Center, Univ. of California.

Lubis. 2014. Pengaruh perbandingan nanas dengan pepaya dan konsentrasi gum Arab terhadap mutu fruit leather. Skripsi. Fakultas Pertanian, Universitas Sumatera Utara, Medan.

Marpaung, L., R.M. Sinaga. 1995. Orientasi perlakuan pengeringan dan kadar garam terhadap mutu irisan kering bawang putih. Bul. Penel. Hort. 27(3): 143-152.

Mohamed, S., R. Hussein. 1994. Effect of low temperature blanching, Cysteine-Hcl, N-Acety-L-Cysteine, $\mathrm{Na}$ Metabisulphite and drying temperature on the firmness and nutrient content of dried carrots. J. Food Process. 18: 343348 .

Ong, S.P., C.L. Law. 2010. Hygrothermal properties of various foods, vegetables and fruits. In: Jangam, S.V., C.L. Law, A.S. Mujumdar. Drying of foods, vegetables and fruits, Singapore, pp. 31.

Pundari, G.A.P., I.M.S. Utama, N.L. Yulianti. 2019. Pengaruh perlakuan uap etanol terhadap mutu dan masa simpan buah manggis (Garcinia Mangostana L.). J. BETA (Biosistem dan Teknik Pertanian). $7(1)$. Doi: https://doi.org/10.24843/JBETA.2 019.v07.i01.p09

Rahman, M.S. 2005. Dried food properties: challenges ahead. Drying Technology. 23(4): 695-715.
Raponi, F., R. Moscetti, D. Monarca, A., Colantoni, R. Massantini. 2017. Monitoring and optimization of the process of drying fruits and vegetables using computer vision: a review. Sustainability Vol. 9: 1-27.

Rhim, J.W., Y. Wu, C.L. Weller, M. Schnepf. 1999. Physical characteristics of a composite film of soy protein isolate and propyleneglycol alginate. J. Food Sci. 64(1): 149-152.

Risnayanti, S.M. Sabang, Ratman. 2015. Analisis perbedaan kadar vitamin $\mathrm{C}$ buah naga merah (Hylocereus polyrhizus) dan buah naga putih (Hylocereus undatus) yang tumbuh di Desa Kolono Kabupaten Morowali Provinsi Sulawesi Tengah. J. Akad. Kim. 4(2): 91-96.

Safefood 380 Inc. 2012. Water activity $\left(a_{\mathrm{w}}\right)$ in foods: a white paper. https://safefood360.com/resources/Wat er-Activity.pdf, accesed on 12 Nov. 2021.

Sandulachi, E. 2012. Water activity concept and its role in food preservation Technical University of Moldova. Uploaded in RG on January 2012.

Sarobol, M., P. Sarobol, S. Teeta, W. Pharanat. 2018. Investigation effective moisture diffusivity and activation energy on convective hot air drying assisted extraction of dragon fruit slices. J. Phys.: Conf. Ser. 1144012062.

Shabrina, Z.U., W.H. Susanto. 2017. Pengaruh suhu dan lama pengeringan dengan metode cabinet dryer terhadap karakteristik manisan kering apel varietas Anna (Malus domestica BORKH). Jurnal Pangan dan Agroindustri. 5(3): 60-71. 
Somjai, C., T. Siriwoharn, K. Kulprachakarn, S. Chaipoot, R. Phongphisutthinant, P. Wiriyacharee. 2021. Utilization of maillard reaction in moist-dry-heating system to enhance physicochemical and antioxidative properties of dried whole longan fruit. Helyon Vol 7 Issue 5. https://doi.org/10.1016/j.heliyon.2021. e07094

Srikiatden, J., J.S. Roberts. 2007. Moisture transfer in solid food materials: a review of mechanisms, models, and measurements. Int. J. Food Properties, 10: 739-777. Doi: $10.1080 / 10942910601161672$

Suharyanto. 2009. Aktivitas air $\left(\mathrm{A}_{\mathrm{w}}\right)$ dan warna dendeng daging giling terkait cara pencucian (leaching) dan jenis daging yang berbeda. Jurnal Sain Peternakan Indonesia, Universitas Bengkulu, Bengkulu. 4(2).

Tjahjadi, Carmencita. 2008. Teknologi Pengolahan Sayur dan Buah, Volume 2. Bandung: Widya Padjajaran.

UNECE, 2014. UNECE Standard DDP-25: Dried Mango. United Nations, New York and Geneva.

UNECE, 2014. UNECE Standard DDP-28: Dried Pineapple. United Nations, New York and Geneva.

Widodo, W.D., K. Suketi, F. Maulida. 2020. Studi degreening, kesegaran, dan daya simpan buah naga merah (Hylocereus polyrhizus (Weber) Britton \& Rose) untuk menentukan kriteria panen optimum. J. Agron. Indonesia, 48(3): 314-322.

DOI: https://dx.doi.org/10.24831/jai.v48i3.3 3065.

Winarno, F.G. 2004. Kimia Pangan dan Gizi. Gramedia Pustaka Utama. Jakarta
Yadav, A.K., S.V. Singh. 2014. Osmotic dehydration of fruits and vegetables: a review. J. Food. Sci. Technol. 51(9): 1654-1673. DOI: 10.1007/s13197-0120659-2.

Yan, Z., M.J. Sousa-Gallagher, F.A.R. Oliveira. 2008. Shrinkage and porosity of banana, pineapple and mango slices during air-drying. J. Food. Eng. 84: 430-440. 